This is an open access article under the terms of the CC-BY 3.0 License.

Peer review method: Double-Blind

Date of acceptance: December 11, 2020

Date of publication: January 08,2021

Original scientific article

DOI: https://www.doi.org/10.47305/JLIA2163038ea

\title{
ENERGY AND GEO-ECONOMICS: EVIDENCE UNDERPINNING RUSSIAN INTERVENTION IN SYRIA
}

\author{
Nada El Abdi \\ French Institute of Geopolitics, Paris, France \\ ORCID iD: https://orcid.org/0000-0001-9807-5331 \\ elabdi.ifg@gmail.com
}

\begin{abstract}
Since September 2015 and the Russian military intervention in the country, the interests in Syria have been numerous and of great importance for the actors involved in this conflict. The interests in Syria are numerous and of great importance for the actors involved in this conflict. Russia, like the Allies and opponents of the Bashar Al-Assad regime, is fighting for geopolitical, geo-economic, or ideological reasons. The Middle East region finds itself shaken by the sharp resurgence of a confrontation between actors allied to the United States, other allies of Russia, and this Syrian crisis thus impacts the geopolitical configuration of the region. This paper presents an analysis of the Russian intervention strategy in Syria. We argue that Russia intervened in Syria to strengthen the already existing Russian-Syrian alliance, to curb extremist proliferation, and to take advantage of Syria's strategic position. The objective is to determine the reasons for the Russian military intervention in Syria related to energy and geo-economic interests. The Russian intervention in Syria was an ideal opportunity to draw closer to several powerful states in the region and a way to benefit from positive spin-offs on its arms market and hydrocarbon road plans. Despite the risks and costs associated with defending the Syrian regime, Moscow has secured its political and economic power in the Middle East.
\end{abstract}

Keywords: Energy; Geo-Economics; Military Intervention; Russia; Syria 


\section{INTRODUCTION}

Having the largest natural gas reserves in the world and being the second-largest oil exporter, Russia is seeking to extend its influence and reach as many world markets as possible. Putin's administration also seeks to maintain and increase its economic power, particularly in Europe and the Middle East, while creating strong alliances. The Syrian conflict is said to have brought Russia closer to several Middle Eastern powers, presenting it with new economic opportunities. Thus, Russia seeks to maintain the energy dependence of several neighboring countries. Moreover, Vladimir Putin uses many ingenious and cunning strategies to achieve his objectives.

Its large gas resources, the efficiency of its distribution system, and its proximity to a large energy-deficient customer base make Russia a price generator for gas. Moscow has managed to use price reductions and long-term delivery contracts to push other states to support it in its political decisions.

To achieve its goals and maintain its ability to develop appropriate policies for its energy client states, Moscow continues to work to create and maintain a monopoly on the production, transmission, and distribution of resources. It is also successfully resolving political disagreements over the reduction of oil and gas exports. Second, it uses supply cuts as a foreign policy weapon against countries resisting Russia's increased influence in their political or economic affairs.

More than 20 states are involved in the Syrian civil war and hundreds of different armed groups were fighting on its territory. Allies of the Syrian regime, including Russia, Iran, and China, prevented the overthrow of the Syrian government with their military, political and economic support. The Syrian crisis has had disastrous repercussions not only on Syrian territory but also on the region. The persistent involvement of several actors during the many years of war in Syria has led several researchers to study the geostrategic importance of this state in the region. It has allowed them to consider the policies of Russia, Iran, and China along with other important countries' policies such as the USA, Israel, Turkey, France, UK, Saudi Arabia, UAE, in their studies of the new geopolitical configuration of the Middle East.

This paper will be to define the reasons behind the Russian intervention in the Syrian conflict. We will therefore try to deconstruct this analysis by studying both the economic and political cooperation sought by Russia and the other key states it is trying to get closer to achieve its objectives in Syria and the region. 


\section{ENERGY POTENTIAL AND RUSSIAN-SYRIAN COOPERATION}

\section{Russian Interests in the Hydrocarbons Sector}

Before the beginning of the Syrian crisis, the country was one of the oil and gas producers in the Eastern Mediterranean. Most of its fields were in the east of the country, near the Iraqi border, or in the center of the country, east of the city of Homs. In 2010,90\% of its exports went to the European Union (Gobat and Kostial 2016). In addition to the damage caused during the conflict, both the EU and the US sanctions and embargoes on Syria no longer allowed these multinationals to continue production. Thus, much of the degradation of the Syrian economy can be attributed to the considerable deterioration of oil and gas exports, as well as the drastic decline in tourism, the two largest pre-war contributors of income to the country (Cordesman 2017).

Even with the multiple losses in the oil and gas sector, the Syrian army continues to prioritize the management of its energies, as well as the reconquest of its energy territories under the Islamic state. The latter is essential for electricity production to meet the needs of the Syrian population and to increase the country's economic rents. Moreover, it was also important for the regime and its allies to cut off the resources of the rebel groups. In addition to the refineries under the control of different factions, the production of crude oil in fields controlled by the Syrian government had fallen drastically. It has been estimated that oil rents fell by $98 \%$ of GDP between 2010 and 2014 (Gobat and Kostial 2016). Moreover, GDP fell from 4.7 to 0.14 billion dollars between 2011 and 2015 (Coface 2019). Thus, the lack of fuel caused a shortage of generated electricity, affecting the primary sector and the processing industry.

The year 2011 was marked by new opportunities in the oil and gas sector in Syria. Indeed, a new strip of natural gas has been discovered in the Homs region, contributing to the country's energy development (Aşcl 2018). New sources of oil were also discovered in 2015 in the controversial Golan Heights, a Syrian territory occupied by Israel since 1981 (Nimmo 2019). Finally, the most important discovery is that found in the Levantine Basin, where Syria has an interesting future in the offshore oil and gas industry. This Syrian energy potential explains some of the reasons why states such as Russia are keen to become involved in Syria.

The multiple political turmoils that the Arab world has experienced in recent years has greatly overshadowed the accelerated exploration of the oil and gas potential of the Levantine Basin. Some Levantine countries have already begun to exploit their discoveries, but others, such as Syria, are backing off because of political conflict. A large source of hydrocarbons in the waters of the Syrian west coast has been discovered and projects for its exploitation have been initiated (Paraschos 2013). 
Moreover, the Syrian Oil Minister has stated that Syria estimates that it holds 1250 billion $\mathrm{m}^{3}$ of gas along the country's Mediterranean coast. A 25 -year contract was signed in 2013 between the Russian company 'Soyuz Nefte Gaz' and the Ministry of Oil and Mineral Resources for exploration along Syria's Mediterranean coast (Aşcı 2018). However, the prolongation of the war suspended the project in 2015, to resume in 2019 under less risky conditions. It is believed that such projects in Syria would be crucial for future Russian investment opportunities, as well as for the possibility of joint ventures in this sector. Undoubtedly, most of the profits will go to the Russian investor during the years of the agreement. However, Syria will be able to benefit from new infrastructure, an improvement in its oil industry, technology transfer, management training, and opportunities in the international market (Henderson 2013).

The importance of Syrian hydrocarbons alone does not justify Russian intervention in Syria. One important reason for its involvement in Syria is the geostrategic position of that state. Syria is the exit point from the energy routes to Europe. Also, the Middle East region contains most of the world's oil and gas resources. All countries wishing to exploit and export these resources by land must pass through Syria to get them to the most attractive market, which is Europe. Thus, Russian control of Syria's energy industry would give Moscow not only power over Syrian energy prices and delivery, but also influence in the Middle East region. Indeed, control over Syria's hydrocarbon energy lines is crucial for Russia, as it could give it the ability to influence energy prices in its favor.

The reconquest of the land taken by the Islamic State was not strictly a military objective. It was also a paramount strategically economic objective for the Russian intervention in Syria. Shares were promised to the Russian companies for each energy territory that came back under the control of the Syrian state (Pichon 2018).

\section{Military and Strategic Cooperation}

Russia has pledged to stand up to the international community to maintain AlAssad, whose departure would prove disadvantageous for Russia and its oil and gas companies. Thus, Moscow continues to use its veto power and its international political power to support the government of Bashar Al-Assad to prevent Syria from suffering the same fate as Libya. The conflicts in Libya and Iraq have resulted in significant economic losses for Russia and have made it clear that such scenarios should not be repeated in Syria (Kozhanov 2016). Syria remains a key partner in the Russian arms market, even if its purchases do not match those of some Middle Eastern states. This trade is of importance for Russia since its arms exports have become the main source of employment in the military-industrial sector after the collapse of the Soviet Union. At the same time, Russia sought to resolve the conflict by leaving its Syrian ally in place, allowing a reduction in Russia's military role and legitimized its presence in Syria. 
To this end, Russia has invested in rebuilding the institutions of the Syrian state, the regular army. Its diplomacy was aimed at bridging the gap between the regime and the 'acceptable' elements of the opposition who were prepared to accept a settlement in which Assad would remain in power (Hinnebush 2020). This remained unacceptable to a large part of the opposition as well as to the Western powers.

The commitment of Russian diplomacy during its intervention in Syria has shown the international community that any decision concerning Syria will have to go through Moscow. The presence of Russian armed forces in Syria was another opportunity to showcase their military capabilities. It should be added that this military presence made the 'no-fly zone' virtually impossible in Syria and also gave Russia its own EEZ for the use of its S-400 missile system and its missile cruiser Moskva (Machnikowski 2015). Russia has demonstrated and defended before the international community the principles of territorial integrity and non-interference in the internal affairs of states.

The Russian operation has become "a demonstration of Russian power and a demand for a greater role in world affairs" (Bartenev 2018, 758). The Russian military presence dates to the 1970s and its intervention in Syria has significantly increased this presence thanks to its naval base in Tartous. Indeed, one of Russia's goals in Syria can be attributed to obtaining new military zones. The Syrian regime has granted Russia's army and private military troops military zones, to help to regain control of its lost territories (Souleimanov and Dzutsatti 2018). The continuation of the conflict required Russia to establish an airbase on Syrian territory to ensure the protection of Syrian airspace and the execution of military operations in the Mediterranean. Thus, Russia officially signed an agreement in August 2015, authorizing it to establish an airbase at Hmeimim in Latakia. This agreement authorizes the deployment of Russian aircraft and soldiers in Syria and the construction of new military bases in the country to launch military operations at the request of the Syrian regime (Hetou 2019). In October 2016, the agreement on the permanent control of the strategic airbase and the indefinite deployment of air forces was ratified.

In addition, this agreement doubles the space available for warships and guarantees the right to control an airbase. Its entry into force in January 2017, therefore, guarantees Russia sovereignty over its new zones, thus giving Russian forces full control over these territories. More than 63,000 Russian military personnel have received combat training in Syria, including more than 25,000 senior officers, 434 generals, and more than 4,300 artillery and rocket specialists (Daher 2018). New weapons developed by the Russians were used or tested in Syria, which may show that Syrian territory was as much a battlefield as it was a testing ground for Russian weapons. The alliance and the Russian presence in Syria have given Moscow access to the warm waters of the Mediterranean Sea as well as a geostrategic rapprochement with Syria's neighboring countries. Also, Syria's west coast lies on the Mediterranean coast, positioning it in an interesting and highly coveted center. 
Moreover, the use of a naval base in Tartus, on Syria's Mediterranean coast, was granted to the Russians long before the conflict began. This base was granted to the Soviet Union in 1971, allowing them to avoid the passage through the Turkish Straits so much disputed by the USSR earlier. With the prolongation of the Syrian conflict, this base is a military-strategic tool of extreme importance serving both the Russians and the Syrians. Its operational capacity continues to strengthen, the Russian military intervention has led to the deployment of more than 1700 Russian military specialists and the dispatch of different types of warships and transport (Daher 2018). Thus, the Tartous Naval Base is in the process of becoming a permanent military naval base, as part of Russia's enlargement plans.

\section{RUSSIA BETWEEN ALLIANCES AND PARTNERSHIP IN THE MIDDLE EAST}

Russia has been able to draw closer to certain Middle Eastern powers since its involvement in the Syrian conflict. The relations it has built continue to bear fruit today.

Russia and Iran have competing interests in Syria and Assad's continued rule, for the time being, are one of their few points of convergence. So far, Iran has provided Assad with more boots on the ground and kept him afloat financially, while Russia has focused on political and air support. Assad cannot afford to lose either Iran or Russia, as they complement each other, and he has played both roles. Since the beginning of the financial crisis, Assad has been rising to maximize his falling margin of control (Shaar 2019). The Iranian case is an interesting and uncertain partnership for Russia. Iran is a strong ally of Al-Assad and its level of involvement is very broad and covers military, economic and political aspects. Nevertheless, it is easy to conceive of certain differences arising between Iran and Russia on military, energy, and post-conflict profit issues within Syria's borders. Both Russia and Iran are seeking power and geo-economic influence in the region. However, their discourse before the international community remains the same, regarding the maintenance of Bashar Al-Assad and the future of Syria.

The Syrian government signed a landmark pipeline agreement in July 2011 with Iran and Iraq, changing the planned pipeline map in the Middle East. This agreement was signed after Syria refused to accept Qatari gas and oil pipeline projects that would cross its territory, possibly to Europe, in 2009 (Ghoble 2017). The pipeline would pass through the Iranian port of Assalouyeh, then through Iraqi territory, through Damascus, and finally to Europe through the construction of new pipelines in the Mediterranean Sea. This project was to be completed in 3 years and cost nearly 10 billion dollars. Nevertheless, it had to be interrupted during the Syrian conflict. Such a project would have contributed to the export of Iranian gas and competition on the energy market 
with Russian and Qatari gas (Sogoloff 2017). The sanctions imposed on Iran completely blocked this project since the products could not be sold to Europe. It is therefore here that one can understand the opportunities that Russia is seeking to exploit. Indeed, Iran remains Russia's best partner in the Middle East. Putin is keen to create agreements for the transport of Iranian gas with Russian energy companies. If Western sanctions are withdrawn, Iran will begin again to consider its project towards the European market (Aşcı 2018). Thus, Iran remains a great rival for Russia, so it is more profitable for Russia to create a partnership with Iran than to have it as a competitor. As a result, it also brings the Russians closer to their goal of European energy dependence.

In 2016, Russia reconsidered its strategic objectives in Syria, when the West did not seem to offer it interesting negotiation plans. This thus prompted the Kremlin to strengthen its support for the Syrian regime and to cooperate with Iran. Despite the hardening of Western policy in the face of Russian adventurism on the Syrian question, Russia has been maneuvering to ease Western sanctions against it.

However, on the military side, this Russian-Iranian partnership does not oblige Iranian-backed armed groups, in particular, the Al-Quds Force and Hezbollah, to carry out orders from Russia in the long term, despite the ground support they provide to Russian operations. On the one hand, it is not profitable for Moscow to refuse Iranian military-strategic assistance, as this would force Russia to significantly increase its ground presence on Syrian borders. On the other hand, Moscow is trying to remain vigilant in this partnership, which could affect its relations with other states that it is trying to maintain or improve (Kozhanov 2017).

A full-fledged military alliance with Iran could have consequences for Russian diplomacy towards Israel or the countries of the Gulf Cooperation Council (GCC). For the time being, the military-strategic partnership between the two countries is limited to information exchange and occasional coordination on Syrian territory.

Between 2016 and 2018, Moscow created the $5^{\text {th }}$ and $6^{\text {th }}$ Corps, which recruited different pro-government armed groups, amnestied rebels, and army defectors and integrated them into a strong military infrastructure under tight central government (and Russian) control. This was intended to diminish Iranian influence on militias and the Syrian military while strengthening the Syrian military as a critical state institution (Khlebnikov 2020).

The conflict in Syria now seems to be subsiding and discussions for reconstruction between allies of the Al-Assad regime are accelerating. As one of AlAssad's main allies and a major contributor to its maintenance since the beginning of the conflict, Tehran is being presented with all kinds of opportunities in Syria at the end of the conflict. However, Moscow's notoriously successful involvement would have taken a large share of Iran's opportunities for profitable projects or forced it to share the profits with Russia. Taking this into account, Iran rushed to sign numerous protocols from the beginning of 2017 (Pichon 2018). It has managed to negotiate its place in the 
reconstruction of Syria, by getting involved in sectors such as mobile telephone networks, mining, especially phosphate mining, the agricultural sector, and the port management of Latakia. Moreover, there have already been several Russian and Iranian foreign direct investments (FDI) in Syria since the beginning of the conflict, which seems positive for the immediate need for development aid. Moreover, Iran is preparing to take a leading role in the reconstruction of the country's pipelines and essential buildings, given that it is the largest producer of cement and iron in the Middle East (AlSaadi 2015).

On the issue of investment sharing, the most significant will be the oil and gas industry, particularly the pipeline, which would change Moscow's plans (Kozhanov 2017). Moreover, Moscow seems dissatisfied with the proximity and power granted to Tehran in the management of the port of Latakia. Moscow and Tehran are trying to monopolize Syria's main sources of profits, provoking another competition between them. These two regional powers should also be ready to protect themselves against the possibility of American economic sanctions targeting their companies involved in reconstruction in Syria (Bartenev 2018).

Turkey

Russia has managed to get closer to Turkey, despite their opposition in Syria and its relations with Iran. As a guardian of the straits, Turkey is a pivotal state in the Mediterranean that has been able to take advantage of its position between the continents and seas where it is located. However, like many European countries, Turkey remains dependent on Russia in terms of energy. It is its main dependent partner, importing more than $55 \%$ of its natural gas from Russia and $35 \%$ of its coal (Prontera and Ruszel 2017).

Turkish energy routes are not only among the Russian geostrategic plans but also among some powerful actors in the Middle East region who want to make use of this transit space (Mocilnikar 2018). It should also be revealed that almost all its gas is imported, as Turkey is fully dependent on Russian gas (Prontera and Ruszel 2017). Thus, one can understand Turkey's desire for energy diversification, but also the Russians' determination to curb these plans. The seriousness of the Syrian conflict and the Russian/Iranian involvement have blocked potential projects for new energy routes to Europe. Turkey was interested in several pipeline projects proposed by various ArabPersian countries and Israel, intending to pursue its energy diversification plan. If Turkey decides to go ahead with the project, the pipelines will have to cross through Syria's Exclusive Economic Zone (EEZ), where Russia has control. Otherwise, it will have to pass through the EEZ of Cyprus, with which Moscow has good relations, unlike the one between Ankara. Also, an agreement has been formalized between Russia and Cyprus giving the Russians the right to use Cypriot port and airport facilities during their 
intervention in Syria. The allies of the Syrian regime shall under no circumstances allow the execution of such a pipeline project, which could directly harm their market and power in the region.

However, a discussion has taken place between Tel Aviv-Nicosia-Athens on a pipeline project that could not only threaten Russia's planned European energy dependence on Russia but also totally exclude Turkey. The latter would lose its power as a transitional country and block its diversification project, while the Russian gas market would be threatened (Prontera and Ruszel 2017). Thus, Moscow and Ankara have a new common interest in blocking any project that excludes them. Despite the coldness of relations between Moscow and Ankara during a large part of the Syrian conflict, their relations were quickly rekindled. The resumption of the 'Turkish Stream' gas pipeline project in partnership with the Russian gas giant Gazprom, to connect Russia to Turkey. This created a distance between Turkey and the West, which Russia welcomed.

Erdogan is thus more provocative towards the West, which caused Westerners to be perplexed by his authoritarian habits. Russia has been able to use its presence in Syria to establish a strong influence in the Middle East region. It has also countered the Western influence present in the Middle East by moving closer to the only Eastern member: Turkey. Moreover, a recent agreement between Russia and Turkey provides for the construction of a nuclear power plant in Akkuyu, Turkey (Aşcl 2018). This Russian construction will make the plant operational by 2023 and will cost nearly $\$ 20$ billion. This agreement could be the beginning of the advent of Russian-Turkish relations.

An agreement was recently reached between Turkey and Russia for the purchase of four S-400 anti-aircraft batteries. So far, two other countries have concluded this agreement with Russia, namely China and India. Several states are also considering making the same purchase, which rivals the US arms market and the power they have in some of these regions. This agreement amounts to nearly $\$ 2.5$ billion and remains controversial because of Turkey's alliance with NATO (Taylor 2018). Indeed, NATO is concerned about this purchase, as there is nothing to prevent Turkey from buying arms from a country outside the organization.

Gulf Monarchies

Today, the energy plans of the Gulf monarchies are the most threatening for Russia. Only ten Middle Eastern countries hold nearly half of the world's oil reserves and more than $40 \%$ of its gas reserves. These include Saudi Arabia, Qatar, the United Arab Emirates, Kuwait, Bahrain, and Oman. Most of the latter are members of the Organization of the Petroleum Exporting Countries (OPEC). Also, the above-mentioned pipeline project from Qatar to Turkey to Europe should have passed through Syria. One of the theories of the impulsive involvement of Qatar and Saudi Arabia against Al-Assad comes from its rejection of this project on its territory. One can therefore understand 
the importance of these petro-monarchies to get rid of this regime to be able to start their pipeline project. However, such a project poses a great threat to Russia, for which Europe is its largest importer of gas. Thus, Putin needed to have some control in Syria to be able to block not only Qatar's plans but also the sale of oil from Saudi Arabia (Aşcl 2018). Having reached an agreement with Iran on the one hand, Putin has developed his plan to reduce and even eliminate the threat from petro-monarchies. This would simultaneously reduce the influence of their American ally in the region. Moreover, Russia signed an agreement towards the end of 2016 with OPEC and Saudi Arabia to limit oil production, which would cause the price per barrel of oil to rise (Mocilnikar 2018). This was well received by its signatories since the agreement was renewed until the end of 2018 (Delanoë 2018) and recently renewed again until 2020. This strategic agreement has stabilized the oil market and its regulation according to market demand. It contributes as much to the stability as to the development of the sector. On the other hand, it has also helped to prevent price declines caused by the production of predominantly American hydrocarbons.

While Russia and the Gulf monarchies are competitors in the global oil and gas market, they are also rivaling at the political level. These Petro-monarchies have allied themselves with the United States over time, strengthening Western influence in the region. However, Russia has developed good relations with the petro-monarchies, despite its alliance with Iran, in addition to differences over the Syrian conflict. Putin has shown leadership by signing an agreement with OPEC to which his state is not a member and has been able to find common ground between Iran and Saudi Arabia.

Even if Russia and some Middle Eastern states are rivals on various fronts (economic, political, ideological), Moscow retains credibility through diplomatic persuasion to reach an agreement with all the players in the region. Nevertheless, Russian relations with rival powers represent a risk for Moscow. If its relations with Iran are not maintained prudently, Russia risks first degrading its relations with the GCC. By doing so, it aims to affect the potential for investment in the Russian economy, provoke Sunni Islamist movements in Russia and finally undermine the diplomatic efforts Russia is working on to resolve the conflict in Syria. In this way, its activism and patience on energy, geopolitical and security issues in the Middle East have given it a foothold in the region's affairs with several rival states (Delanoë 2018).

For some years now, Putin has remained cautious in the face of tensions between Qatar and Saudi Arabia since the summer of 2017, which led to Qatar's decision to leave OPEC in 2019. Faced with this situation, Moscow has remained neutral to protect its national interests and has not refrained from working on agreements with each of them. Indeed, Russia has recently discussed more than fifteen agreements with Saudi Arabia, including the construction of a nuclear power plant in Saudi Arabia and a package of arms sales. Aside from the many military and technical cooperation agreements signed between Russia and Qatar, the latter also seems interested in procuring the famous S- 
400s, which caused the Saudi protest (Kabalan 2018). On the other hand, Qatar recently invested in the Russian economy with the purchase of shares in the Russian oil company Rosneft, in the amount of 11.3 billion dollars (Karasik 2017). In short, the diminishing American involvement in the region, the inconsistency and unpredictability of the Trump administration, and the Russian victory in Syria have motivated the petro-monarchies to turn to Russia. This has thus presented Russia as a major player in the security of the region.

\section{CONCLUSION}

Because of the various points raised in this paper, several observations emerge. First of all, the Russian military intervention in Syria since 2015 was not part of the application of the grand Middle East or even global strategy but of a pragmatic search for the projection of energy and economic interests, and an attempt to resolve the closest concerns in the region, which are the primary concern of its foreign policy. This paper tried to highlight the geo-economic rationale for the Russian intervention in Syria. It aimed to dissect several causes of the Russian strategy in the Syrian conflict. The analysis allowed us to investigate how Russia managed to regain the powerful position it had at the time of the USSR on the international scene. Putin was able to take advantage of every international event to accumulate geopolitical and geo-economic gains in the Middle East. His alliance with the Syrian regime, as well as his preponderant participation in the military support to Al-Assad in the civil war, enabled him to become a powerful player in the stakes of the region. Any issue or decision related to Syria now goes through Moscow. His fight in Syria has enabled him to weaken extremist groups in Syria to prevent the spread of extremist ideology on his territory or in those of his former Soviet republics. This has thus earned him military zones and shares in the hydrocarbon sector offered by the Syrian regime. This 'war on terror' initiative has been instrumentalized by Russia as an instrument to help it break out of the diplomatic isolation it has suffered for several years in the West (Notte 2016). Syria's geostrategy was crucial for Russia's future hydrocarbon route projects. It was also important for blocking the pipelines of other countries that were likely to compete with its policies aimed at maintaining Europe's energy dependence on its hydrocarbons. Moscow also used its intervention in Syria to draw closer to several Middle Eastern regional powers. Despite the coldness of Russian-Turkish relations during the Syrian conflict, Moscow managed to renew its relations with Ankara. This led to the conclusion of important agreements on armaments, conventional energy, and nuclear technology. Moreover, it used the same tactics with powerful petro-monarchies, notably Saudi Arabia and Qatar. Despite their alliance with Washington, Russia has managed to demonstrate its power with these countries and to reduce American influence. In this way, several agreements were created and linked to the hydrocarbon sector, the most important being the 
Turkish Stream with Turkey. The vision emanating from the Kremlin also secured gains for its arms deal with Turkey. Finally, its intervention in Syria offered new development opportunities, thanks to the cooperation of its Iranian and Turkish allies. Finally, Russia's alliance with these regional powers enabled it to win the war in Syria and strengthen its position in the Middle East. Also, Russia's strategy has highlighted how energy issues and the geo-economy are now setting the pace for political decisions. We have seen that Putin has taken advantage of the differences and issues at stake between certain groups of states in the region to pursue his agenda of energy dependence. 


\section{REFERENCES}

1. Al-Saadi, S. (2015, June). Iran's Stakes in Syria's Economy. Carnegie Endowment for International Peace.

2. AşCI, M. E. (2018). The Energy Policies of EU, Russia, Turkey and Syria. International Journal of Commerce and Finance, 4(1), pp. 96-106.

3. Bartenev, V. I. (2018). Mutually guaranteed obstruction? Russia, the West and Political Dilemmas of Restoring Syria. Vestnik RUDN, International Relations, 18(4), pp. 755-774. doi: 10.22363/2313-0660-2018-18-4-755-774

4. Coface (2019). Risk Assessment. The Syrian Arab Republic, Economic Studies. Available:

5. https://www.coface.com/Economic-Studies-and-Country-Risks/SyrianArabRepublic

6. Cordesman, A. H. (2017, May). If the Fighting Ever Stops: Stabilization, Recovery, and Development in Syria. Center for Strategic and International Studies (CSIS).

7. Daher, J. (2018, September). Three Years Later: The Evolution of Russia's Military Intervention in Syria. Atlantic Council.

8. Delanoë, I. (2018). Russie - pétromonarchies du Golfe : De la tempête à I'accalmie. Confluences Méditerranée, 104(1), pp. 61-71. doi: 10.3917/come.104.0061

9. Gobat, J., Kostial, K. (2016). Syria's Conflict Economy. International Monetary Fund (IMF), Working Paper 16/123.

10. Ghoble, V.T. (2017). Making of Syrian Crisis: The Energy Factor. International Studies, 52(1- 4), pp. 38-52. doi: 10.1177/0020881717714676

11. Henderson, S. (2013, December). Russia-Syria Offshore Gas Deal Injects New Factor into Peace Talks. The Washington Institute.

12. Hetou, G. (2019). The Syrian Conflict. The Role of Russia, Iran and the US in a Global Crisis. London: Routledge India.

13. Hinnebush, R. (2020). The Battle over Syria's Reconstruction. Global Policy, Volume 11(1). https://doi.org/10.1111/1758-5899.12779

14. Kabalan, M. (2018). The Gulf Crisis: The U.S. Factor. Insight Turkey, 20(2), pp. 3349. doi: $10.25253 / 99.2018202 .03$

15. Karasik, T. (2017, March). Why Qatar is Investing so much in Russia? Middle East Institute.

16. Khlebnikov, A. (2020, March). Russia and Syrian Military Reform: Challenges and Opportunities. Carnegie Middle East Center.

17. Kozhanov, N.A. (2016). Russia and the Syrian conflict: Moscow's domestic, regional, and strategic interests. Berlin: Gerlach Press.

18. Kozhanov, N.A. (2017). Russian-Iranian Relations through the Prism of the Syrian Crisis. Insight Turkey, 19(4), pp. 105-124. doi: 10.25253/99.2017194.07 
19. Machnikowski, R. (2015). Russian Manoeuvres in the Dark. The Polish Quarterly of International Affairs, 24(4), 27-II.

20. Mocilnikar, A. (2018, Février). L'Europe, la Méditerranée et l'énergie. Annales Des Mines - Réalités Industrielles, pp. 16-23.

21. Nimmo, K. (2019, March). Syria ready for War to Regain Oil-Rich Golan Heights? Centre for Research on Globalisation. Global Research.

22. Notte, H. (2016). Russia in Chechnya and Syria: Pursuit of Strategic Goals. Middle East Policy, 23(1), pp. 59-74. doi: 10.1111/mepo.12174

23. Paraschos, P. E. (2013). Offshore Energy in the Levant Basin: Leaders, Laggards, and Spoilers. Mediterranean Quarterly, 24(1), pp. 38-56. doi: 10.1215/10474552$\underline{2018997}$

24. Pichon, F. (2018). Enjeux et acteurs de la reconstruction en Syrie. Les Cahiers de I'Orient, 131(3), pp. 153-162. doi: 10.3917/lcdlo.131.0153

25. Prontera, A., Ruszel, M. (2017). Energy Security in the Eastern Mediterranean. Middle East Policy, 24(3), pp. 145-162. doi: 10.1111/mepo.12296

26. Shaar, K. (2019, October). The Syrian Oil Crisis: Causes, Possible responses, and Implications. Middle East Institute. Policy Paper 2019-17.

27. Sogoloff, N. (2017, August). Russia's Energy Goals in Syria. The Washington Institute.

28. Souleimanov, E.A. and Dzutsatti, V. (2018). Russia's Syria War: A Strategic Trap? Middle East Policy, 25(2), pp. 42-50. doi: 10.1111/mepo.12341

29. Taylor, M. (2018, January). Turkey: Russian missile purchase will diversify supply. Oxford Analytica - Daily Brief. 